\title{
Metamorphic core complexes and gneiss-cored culminations along the Mid-Norwegian margin: an overview and some current ideas
}

\author{
Per Terje Osmundsen, Alvar Braathen, Anna Sommaruga, Jan Reidar Skilbrei, \\ Øystein Nordgulen, David Roberts, Torgeir B. Andersen, Odleiv Olesen \\ and Jon Mosar
}

\footnotetext{
From the Palaeozoic to the Cretaceous, crustal thinning in the Mid Norway area was associated with the denudation of gneiss-cored culminations and metamorphic core complexes in the footwalls of major extensional faults. The development of the culminations led to warping and deactivation of early detachments, to the nucleation of new faults in more distal positions and to the exhumation of highgrade metamorphic rocks to more shallow levels in the crust. Some of the culminations and core complexes became part of the erosional template in Mid-Late Palaeozoic time, some were probably exhumed in the Mesozoic, whereas some may never have reached the surface. We present an overview of five types of gneiss-cored culminations and core complexes that have been identified in the field, through the interpretation of offshore, long-offset seismic reflection data. We furthermore address their mechanism(s) of formation, and their role in the progressive evolution of the Mid-Norwegian margin.
}

\section{Introduction}

The multi-stage development of many passive margins, the scale of differential vertical movements involved in their formation and the importance of source areas in the adjacent continent interior shows that, for the most part, present-day shorelines constitute an artificial boundary in passive margin studies. Recent studies in basin dynamics emphasise the source-to-sink perspective, highlighting the importance of the processes that take place in the source areas (e.g. Leeder et al., 1998). The onshore-offshore approach to the continental margin studies provides an opportunity to address both the source and sink, and their evolution through time. In the source areas, structural studies combined with 40Ar/39Ar geochronology and apatite fission track analysis provide a means to link cooling with tectonically controlled exhumation, and to date activity on shear zones and faults. Thus, such studies allow us to assess directly the tectonothermal template that was exploited by erosion during the later rift phases.
Onshore structures are not necessarily easy to trace offshore, and, even if a successful correlation can be made, the implications and importance of this with respect to an understanding of passive margin evolution may be variable. One of the challenges in onshore-offshore studies is, thus, to define common denominators that provide links, not only between individual geological features, but more importantly, between the processes that were involved. In the present contribution, we focus on gneiss-cored culminations and metamorphic core complexes that straddle the Mid Norway passive margin. The formation of a number of these culminations is strongly linked to extensional tectonics and to the exhumation and cooling of rocks that eventually became parts of the erosional template. Most of the culminations are associated with sites of fault nucleation, re-activation and de-activation, and some appear to be controlling the location of major domain boundaries within the Mesozoic rift. The control on fault patterns by the underlying core complexes and culminations suggests that, at least locally, syntectonic sedimentation may have 
been severely affected by the denudation of the metamorphic cores.

Gneiss-cored culminations form in a variety of tectonic environments, including compressional, extensional and strike-slip settings. A common occurrence of gneiss-cored culminations is in the internal parts of orogens, where parautochthonous or autochthonous rocks are exposed in tectonic windows (e.g. Haller, 1971; Ramberg, 1980). A special type of gneiss-cored culmination is the metamorphic core complex, where rocks from the middle or lower crust have become tectonically juxtaposed with non-metamorphic sedimentary rocks. Metamorphic core complexes form in the footwalls of large-magnitude extensional detachments, and are known from a number of highly extended terranes, including the Basin and the Range Province of the western U.S. (e.g. Wernicke, 1985; Lister and Davis, 1989), the Tyrrhenian Sea area (Jolivet et al., 1991), the southwestern Norwegian Caledonides (Norton, 1986; Andersen and Jamtveit, 1990; Fossen, 1992), and from the classic rift zones, such as the Red Sea Rift (Talbot and Ghebreab, 1997). Extensional detachments have been suggested to constitute fundamental elements in the structural architecture of continental margins (e.g. Lister et al., 1991; Fossen et al., 2000; Whitmarsh et al., 2000; Manatschal et al., 2001).

The Mid Norway area (Fig. 1) experienced multi-stage crustal thinning from the Devonian to the Tertiary (e.g. Skogseid et al., 1992). The earliest phases of extension in the Devono-Carboniferous times resulted in a dramatic reduction of the Caledonian orogenic crust and in differential exhumation of the Caledonian nappe pile and basement. Structural products associated with the early phases of crustal thinning are well-preserved onshore Mid Norway (Braathen et al., 2002; Osmundsen et al., 2003), and significant advances have recently been made to understand the thermal consequences of Palaeozoic and later extension in the onshore areas (Eide et al., 2002, 2003 and in press; Redfield in press). As DevonoCarboniferous, late- to post-orogenic extension gave way to successive Late Palaeozoic and Mesozoic rift phases, a complex structural hierarchy was superposed on the extended remains of the Caledonian orogen. Uplift and erosion of the Palaeozoic tectonothermal template continued into the Mesozoic and Tertiary, providing detritus that contributed to the filling of syn- and post-rift offshore basins (e.g. Sherlock, 2001). We aim at an overview of the geometry and the mechanisms of formation of gneiss-cored culminations that occur onshore and offshore Mid Norway. Whereas the exhumation history of onshore culminations are important in a provenance perspective and with respect to re-activation, the development of core complexes in Mesozoic times affected shallow-level structural development and, thus, the syndepositional rift architecture.

\section{Differential exhumation and gneiss-cored culminations onshore Mid Norway}

Late/post-Caledonian extension reworked the Caledonian nappe pile into an array of extensional allochthons bound by ductile-to-brittle, top-WSW shear zones and detachment zones (Braathen et al., 2002; Osmundsen et al., 2003). The configuration of extensional structures, strike-slip faults and gneisscored culminations developed progressively in Devono-Carboniferous times, commencing with deformation along low-angle, medium- to lowgrade extensional shear zones. Some of these shear zones developed into large-magnitude detachment zones that eventually juxtaposed regional gneiss culminations with continental, 'Old Red' sedimentary basins. Others appear to have become deactivated as they were incised by moderate-angle, low-grade, ductile-to-brittle faults (Braathen et al., 2002; Osmundsen et al., 2003). Thus, the Palaeozoic structural framework in Mid Norway includes a large number of important shear zones and faults that cut the Caledonian nappe stack and affect the plan-view outline and the cross-sectional geometry of the onshore tectonostratigraphy.

The gneiss-cored culminations that have been identified onshore Mid Norway fall into three main types (Fig. 2; Osmundsen et al., 2002a). Unmodified, thrust-related culminations (type 1) are preserved in areas away from, and mainly east of, the major extensional shear zones that truncate the Caledonian nappe pile. These particular culminations will not be considered further here. In the areas affected by extension, two main types of culminations developed that show different characteristics with respect to strain pattern as well as to the amount of displacement on bounding shear zones. The type 2 culminations are flanked by a kilometre-thick, ductile, large-magnitude (tens of kilometres) extensional detachment zones, capped by brittle detachment faults, and characterised by extension-parallel folds that developed contemporaneously with extension (Norton, 1996; Séranne, 1992; Chauvet and Séranne, 1994; Krabbendam and Dewey, 1998); i.e., the type 2 culminations are thought to have developed progressively in a 


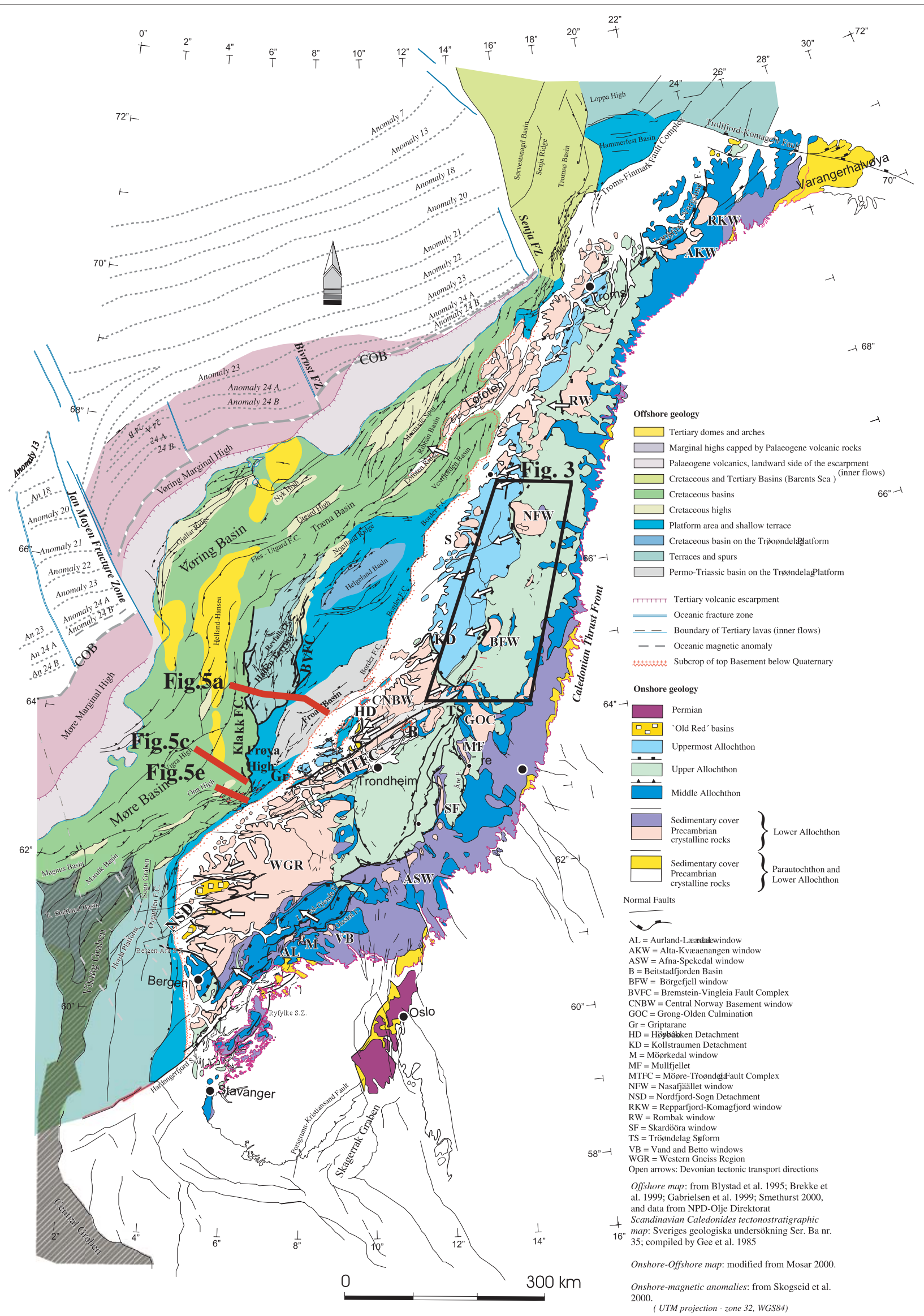

Fig. 1 Onshore-offshore map of Norway and the Norwegian margin, mainly from Mosar et al. (2002). Open arrows indicate generalised tectonic transport directions for Devono-Carboniferous, late/post-orogenic shear zones and faults. 


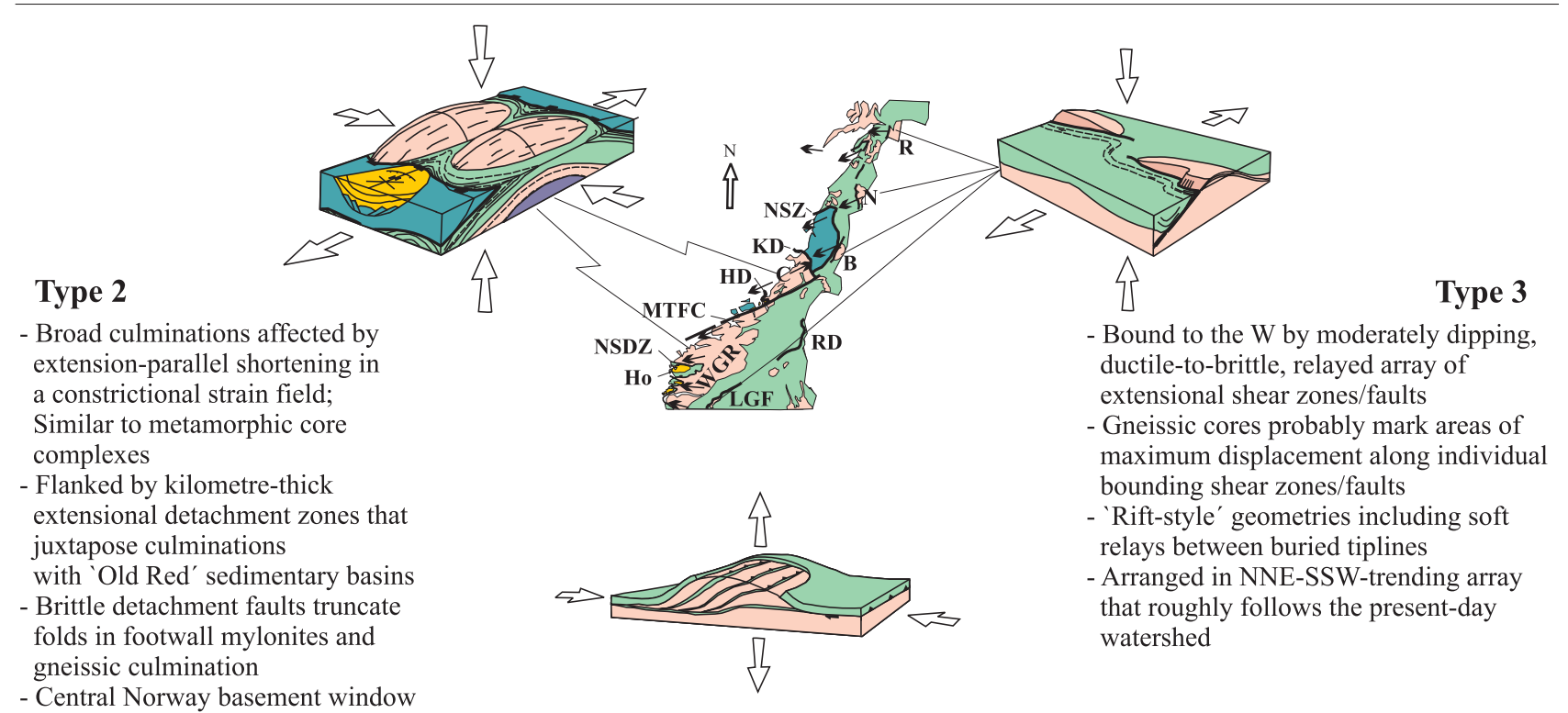

Type 1

Thrust-related culminations; antiformal stacks, duplexes, thrust-ramp antiforms.

Preserved in unmodified form outside areas affected by large-magnitude extension (Finnmark, western Sweden).

Fig. 2 Generalised types of gneiss-cored culminations found in the Scandinavian Caledonides. See text for discussion. Inset map: B-Børgefjell window; Ho - Hornelen Basin; HD - Høybakken detachment; LGF - Lærdal-Gjende Fault; MTFC - Møre-Trøndelag Fault Complex; N Nasafjäll window; NSZ - Nesna shear zone; NSDZ - Nordfjord-Sogn detachment zone; R - Rombak window; RD - Røragen detachment; WGR - Western Gneiss Region.

constrictional strain field (e.g. Krabbendam and Dewey, 1998, Fig. 2). The type 2 culminations are juxtaposed against 'Old Red' extensional basins, believed previously to have developed from Early into Middle Devonian times (Kolderup, 1921; Jarvik, 1949; Allen, 1976). Recent results from 40Ar/39Ar geochronology indicate, however, that the upper parts of the 'Old Red' basin stratigraphy in the outer Trondheim Region are Late Devonian at the oldest, and that the material deposited in the basins was sourced in the (type 2) Central Norway Basement Window (CNBW; Fig. 1; Eide et al., 2003). Thus, some type 2 culminations were exhumed to the surface and were eroded during 'Old Red' basin deposition. The type 2 culminations in SW and Mid Norway resemble metamorphic core complexes, and have been described as such (e.g. Norton, 1986; Braathen et al., 2000).

The array of type 3 culminations (Fig. 2) generally follows the present-day watershed between Norway and Sweden (Mosar et al., 2002). Some of the type 3 culminations have been interpreted earlier as thrust-related culminations (e.g. Greiling et al., 1998), but the identification of an array of relayed, extensional, ductile-to-brittle fault zones along the western margins of the Rombak, Nasafjäll and Børgefjell windows (Fig. 1 and 3; Rykkelid and Andresen, 1994; Braathen et al., 2002; Osmundsen et al., 2003) supports extension-related structural control on gneiss-core denudation. Previous modelling of the top to magnetic basement under the Central Norwegian Caledonides (Sindre, 1998; Olesen et al., 2002) is consistent with vertical separation in the order of $3-6 \mathrm{~km}$ along the margins of the culminations. Thus, the displacements related to type 3 culminations were probably an order of magnitude less than the displacements associated with type 2 culminations. The type 3 culminations show little or no evidence of extension-normal shortening, and may have formed under conditions approximating plane strain or even vertical flattening.

The kinematics of bounding shear zones, the overall culmination geometry and the map-view distribution of flanking nappes indicate that the type 3 culminations resemble the footwall uplifts, commonly associated with normal faults in continental rift zones. In this scenario, the gneissic cores of the culminations mark the areas of maximum footwall uplift (and thus maximum displacement) along the ductile-to-brittle faults that bound the culminations. Correspondingly, an anomalous, ENE-WSW trend of the Caledonian nappe boundaries in the area between the Nasafjäll and Børgefjell windows has been interpreted in terms of a soft relay zone (Fig. 3a; Osmundsen et al., 2003). 

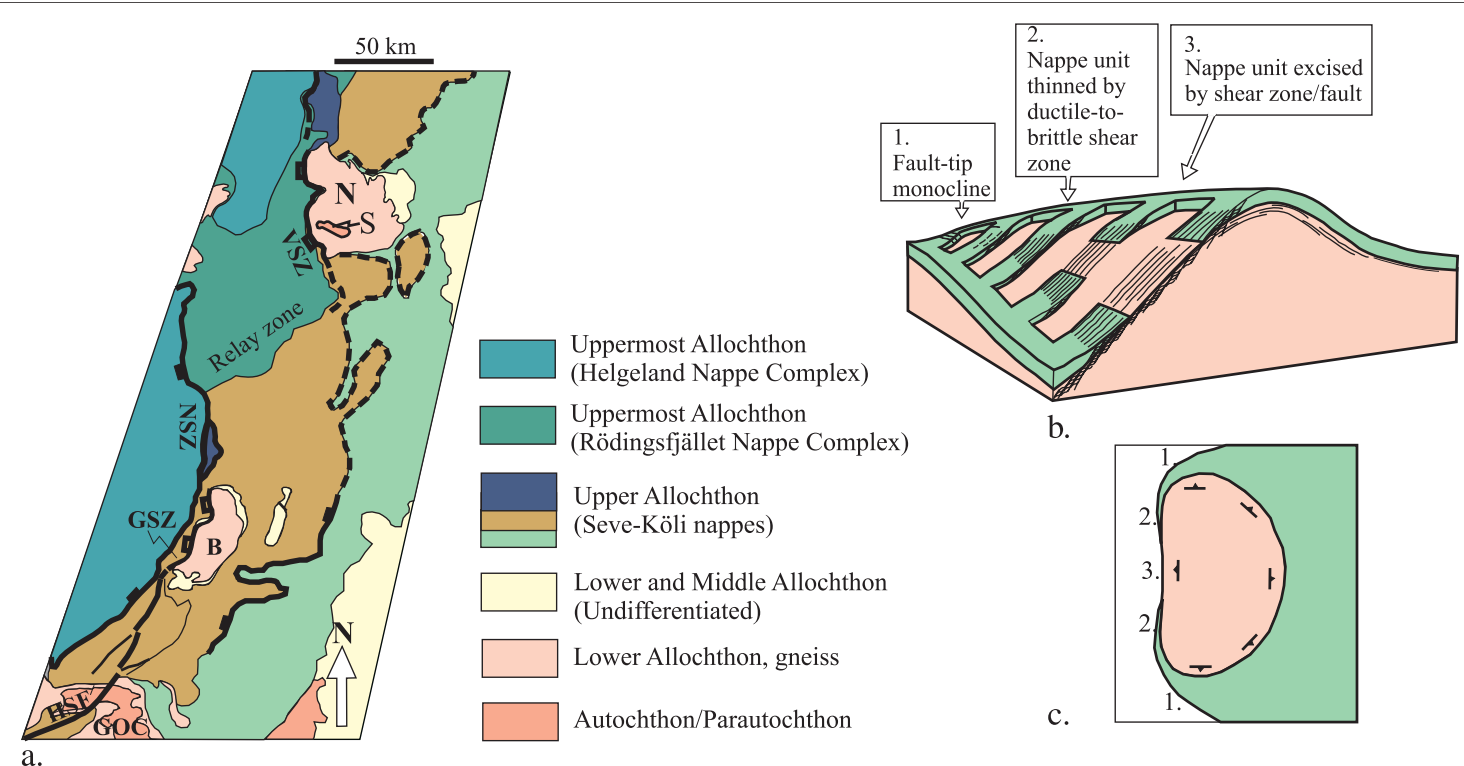

Fig. 3 a. Geological map of part of the North-central Norwegian Caledonides (simplified from Solli 1999, see Fig. 1 for location) with the Nasafjäll (N) and Børgefjell (B) culminations and adjacent nappe units. Note thinning and excision of individual units along the western boundaries of the gneiss-cored culminations. GSZ-Gaukarelv shear zone; VSZ-Virvassdalen shear zone; NSZ-Nesna shear zone (see Braathen et al., 2002 and Osmundsen et al., 2003 for descriptions of culmination-bounding shear zones); GOC-Grong-Olden Culmination; HSF-HitraSnåsa Fault; S-Stokkali Granite (Par-? Autochthon). b. Two-layer fault-growth model for the development of type 3 culminations such as the Nasafjäll and Børgefjell windows. c. Resultant map-view configuration. The model is consistent with: (1) the excision of nappe units along the western margins of the gneiss windows; (2) the monoclinal geometry of nappes along the northwestern and southwestern margins of the windows; and (3) the formation of soft relays with anomalous orientations of nappe boundaries between the windows, as illustrated in Fig. 3a.

An interpretation in terms of displacement gradients along the bounding faults may also explain the thinning and excision of some of the main nappe units along the western margins of the culminations (Figs. 3b-c). A northwards and southwards decrease in the amount of displacement is consistent with the tip line of individual ductile-to-brittle shear-zone segments plunging underneath the nappe pile at the northern and southern margins of the windows, leading to the deflection of nappes that is generally observed around the gneissic cores. This deflection resembles that produced by fault-tip monoclines associated with fault growth, such as described from the syn-rift stratigraphy of the Suez Rift (e.g. Gawthorpe et al., 1997). Late Devonian to Early Carboniferous ages have been assigned to top-tothe-W, low-grade ductile-to-brittle shearing along the western margin of the Rombak window (Fig. 1; Coates et al., 1999). It is likely that shearing and faulting along the Nasafjäll and Børgefjell culminations took place during the same time interval (Osmundsen et al., 2003). However, there are indications of younger rejuvenation, represented by fault slip-directions that cannot be reconciled with the Devono-Carboniferous strain pattern (Braathen et al., 2002). At present, the age of the exhumation of the gneissic cores to the surface is unknown.

\section{The Møre-Trøndelag Fault Complex}

The Møre-Trøndelag Fault Complex (MTFC) is spatially related to both, the type 2 and the type 3 culminations. The Hitra-Snåsa Fault of the MTFC borders the (type 2) Central Norway basement window, and constitutes a SE transfer boundary for the extensional Høybakken detachment (Fig. 2; Séranne, 1992; Braathen et al., 2000). The array of type 3 culminations and associated, ductile-tobrittle fault zones is linked to the south with the MTFC, through a series of relayed fault strands described by Roberts (1998) that show evidence of normal/sinistral displacements ( Fig. 3a). The array of fault strands can be traced towards the GrongOlden Culmination (Fig. 3a), which is displaced 3-4 $\mathrm{km}$ sinistrally by the Hitra-Snåsa Fault (op. cit.). Coupled with the age of the uppermost deposits in the 'Old Red' of the outer Trondheim region, the Late Devonian-Early Carboniferous age of shearing and faulting along the gneiss culminations (Coates et al., 1999; Osmundsen et al., 2003) indicates temporal overlap between shearing and faulting, along the array of culminations and faulting/basin formation in the area of the Høybakken detachment (Fig. 2). Later activity along the MTFC occurred in multiple stages (Grønlie et al., 1991) and includes transtension of 


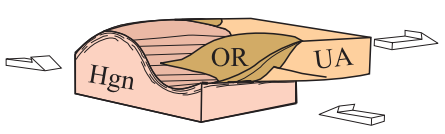

a.

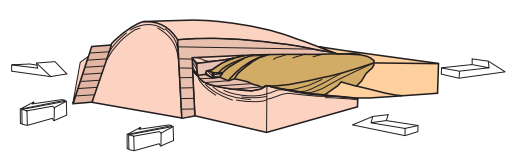

b.

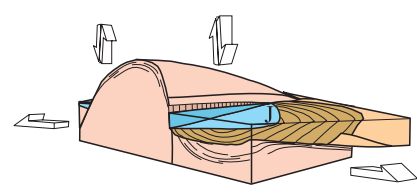

c.

Fig. 4. Cartoon showing conceptually the development of a type 2 culmination (such as the CNBW), sinistral strike-slip faults (such as the MTFC) and sedimentary basins through a) Early- to Mid Devonian, top-to the WSW extension, b) Devono-Carboniferous, contiued extension and sinistral strike-slip (development of MTFC), and c) Jurassic re-activation of strands of the MTFC as normal faults. The changing roles of the MTFC has been documented by previous workers (i.e. Grønlie and Roberts, 1989; Bering, 1992; Séranne, 1992; Braathen et al., 2000). Only phases demonstrably related to basin-forming events have been included in the figure. HGn-medium- to high-grade gneisses and supracrustals, parautochthonous or in the Lower Allochthon; UA-nappe units, belonging mainly to the Upper and Uppermost Allochthon of the Caledonian nappe-stack; OR-'Old Red' sedimentary rocks; J-Jurassic sedimentary rocks.

probable Permian age (Watts, 2001), a phase of dextral re-activation (Grønlie and Roberts, 1989; Watts, 2001) as well as dip-slip re-activation, associated with sedimentation in the Jurassic Beitstadfjorden Basin (Figs. 1 and 4; Bering, 1992; Bøe, 1991; Sommaruga and Bøe, 2002). Recent apatite fission track studies show clear breaks in the derived ages across lineaments that are parallel to the trend of the MTFC; most likely, these breaks reflect Late Palaeozoic and Mesozoic fault-block rotation and differential uplift (Redfield, 2002; Redfield et al., in press). The offshore counterpart of the MTFC has been interpreted to have played an important role during Late Palaeozoic and Mesozoic rifting (Grunnaleite and Gabrielsen, 1995; Gabrielsen et al., 1999).

\section{Gneiss-cored culminations offshore Mid Norway and their influence on rift-zone architecture}

Aeromagnetic data show very strong positive signatures in the Frøya High and parts of the Trøndelag Platform area that are probably related to sources in the deep basement (Skilbrei et al., 2002). During prograde metamorphism, magnetite is commonly produced in mafic as well as intermediate rocks; only parts of the magnetite become redistributed during denudation and retrogression (e.g. Skilbrei et al., 1991). Most likely, the strong positive anomalies result from denudation of strongly magnetic, high-grade metamorphic rocks. The pattern of strong positive magnetic anomalies has been compared to the pattern of onshore type 2 and 3 culminations, to provide a basis for offshore extrapolation of detachment zones exposed in the onshore areas (Olesen et al., 2002; Skilbrei et al., 2002). In the Frøya High example, rough and shallow basement topography may add to the strong positive magnetic signature. Interpretation of long-offset seismic data has revealed two main types of deep-seated culminations. In the southern Trøndelag Platform/Halten Terrace area, a Palaeozoic detachment appears to be warped across the crest of an antiformal culmination that also controlled the ramp-flat geometry of the Mesozoic Bremstein-Vingleia Fault Complex to the east of the Njord field (Figs. 1 and 5a). Another core complex appears to be related to low-angle truncation of a strong, intra-basement reflective band west of the Frøya High by a low-angle detachment fault west of the Klakk Fault Complex (Figs. 1 and 5b). In a NW-SE oriented section, the low-angle detachment west of the Frøya High reveals horizontal separation in the order of $40 \mathrm{~km}$ (Osmundsen et al., 2002b). The northeastern parts of the Slørebotn Sub-basin (Fig. 5c; Blystad et al., 1995) preserves a synclinal depression with rotated, supradetachment fault blocks, a configuration commonly encountered between an exhumed core complex and the detachment breakaway (e.g. Wernicke, 1985). Thus, Mesozoic structuring in the offshore areas also involves large-magnitude normal-faulting and core-complex denudation. The pattern of offshore magnetic anomalies reflects the superposition of these processes upon the Palaeozoic structural template (Skilbrei et al., 2002).

The denudation of deep crustal rocks in the footwalls of large-magnitude Mesozoic faults can be explained by models involving excisement and/or incisement (Lister and Davis, 1989), depending on geometrical and temporal relationships between the inherited Palaeozoic template and the Mesozoic fault systems (Figs. 6a,b). Interpreted seismic lines in the southern Trøndelag Platform area reveal that a gently WNW-dipping to sub-horizontal reflection band underlies rotated, Palaeozoic-Early Mesozoic half-grabens at c. $6 \mathrm{~s}$ TWT (Fig. 5a). The reflection band is interpreted as a detachment zone that may represent the offshore continuation of the onshore Høybakken detachment (Osmundsen et al., 2002b; Skilbrei et al., 2002). Close to well 6407/7-1 


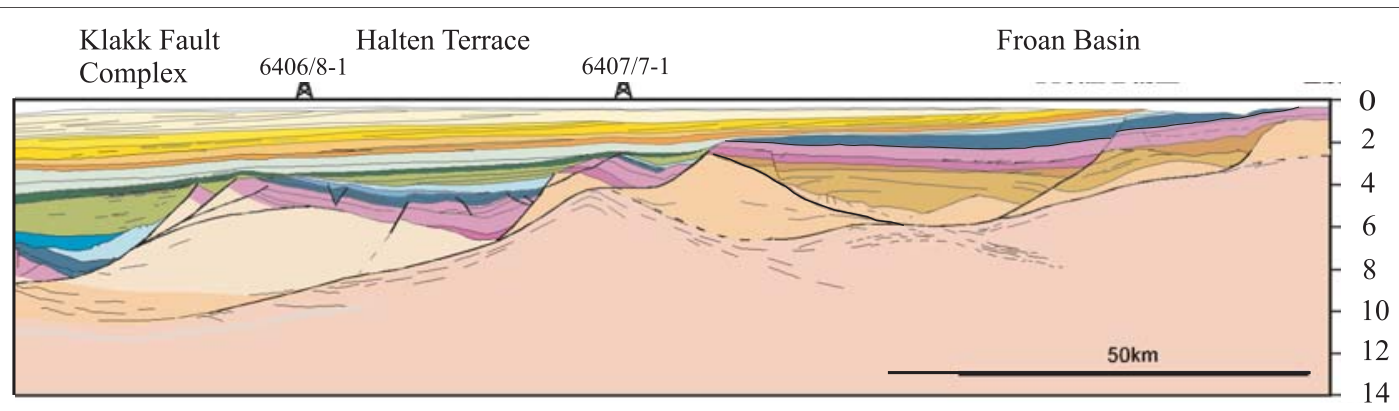

a.

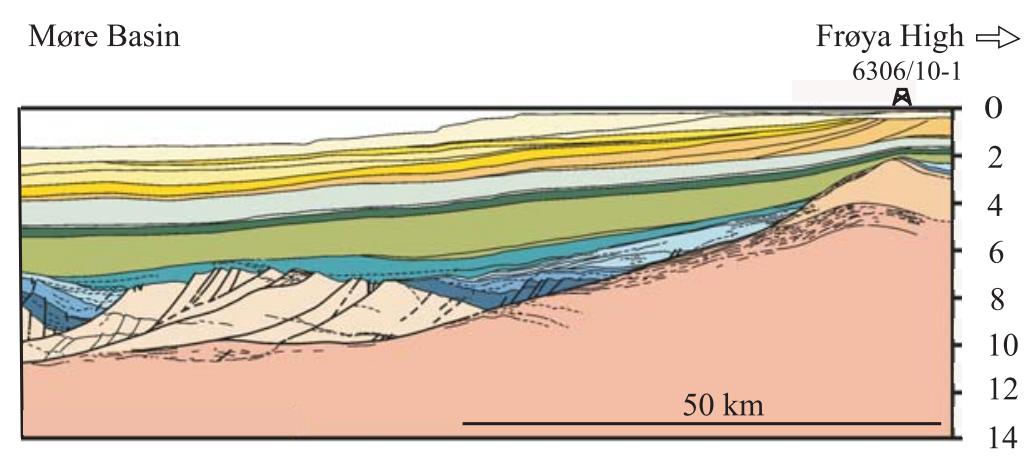

b.

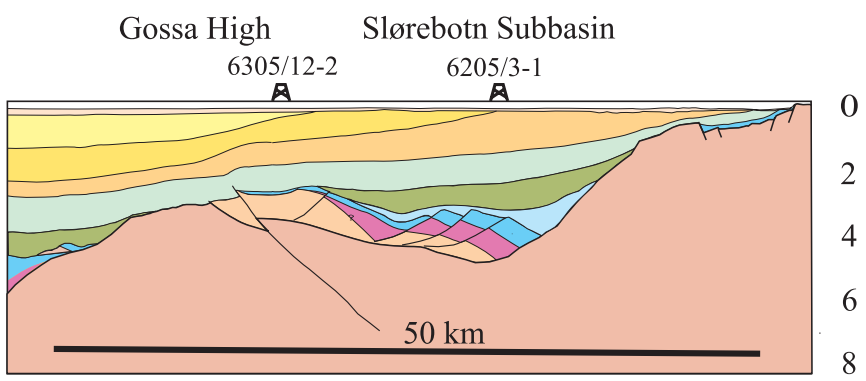

c.

Legend (Please note simplistic subdivision of the Tertiary in c.)

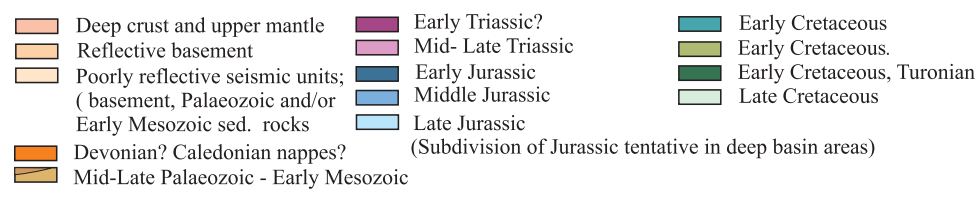

Fig. 5 Interpretations of seismic lines showing evidence for large-magnitude displacements along low-angle Mesozoic detachment faults. (a) southern Trøndelag Platform/Halten Terrace area (Osmundsen et al., 2002), (b) west of the Frøya High (op. cit.) and (c) the NE Slørebotn Subbasin area (interpretation redrawn from Blystad et al., 1995). See fig. 1 for approximate location of seismic lines and text for further discussion.

(Fig. 5a), this reflection band appears to be warped across an antiformal culmination, with the crest positioned at c. $4.5 \mathrm{~s}$ TWT. Two Mesozoic fault splays, one ramp-flat and the other planar, bound the rotated fault block hosting 6407/7-1 in the southeast and in the northwest, respectively. Both faults merge at depth with the NW-dipping flank of the antiformal culmination (Fig. 5a). This fault pattern can be explained in terms of development of progressively younger detachment faults from the Palaeozoic into the Late Jurassic/Earliest Cretaceous (Figs. 6 and 7). Both in this area and in the area west of the Frøya High, the flanks of metamorphic core complexes appear to be important with respect to the location of major domain boundaries in the Mesozoic rift, such as the platform-terrace boundary in the Njord area and the boundary to the deep basin in the area of 6301/ 10-1 (Fig. 5b).

Most likely, the control exerted by the core complex on higher-level fault geometries, as observed in the area of 6407/7-1 (Fig. 5a), in turn affected the stratigraphic architecture in adjacent half-graben basins. The ramp-flat fault east of 6407/ 7-1 most likely owes its geometry to a late phase of denudation of the underlying core complex 


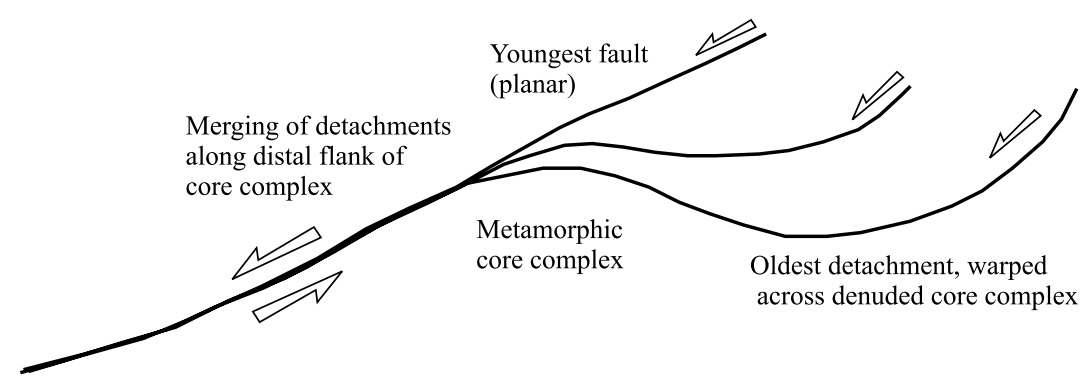

a.

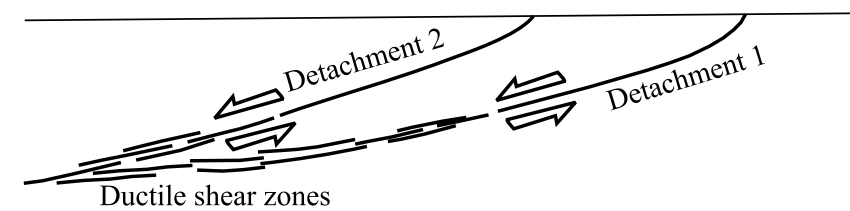

b.

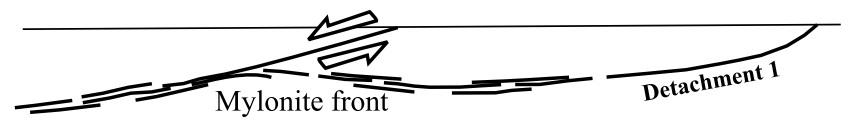

Fig. 6 Models of excision (a) and incision (b) for the formation of metamorphic core complexes (Lister and Davis, 1989). Compare with examples shown in Fig. 5. See text.

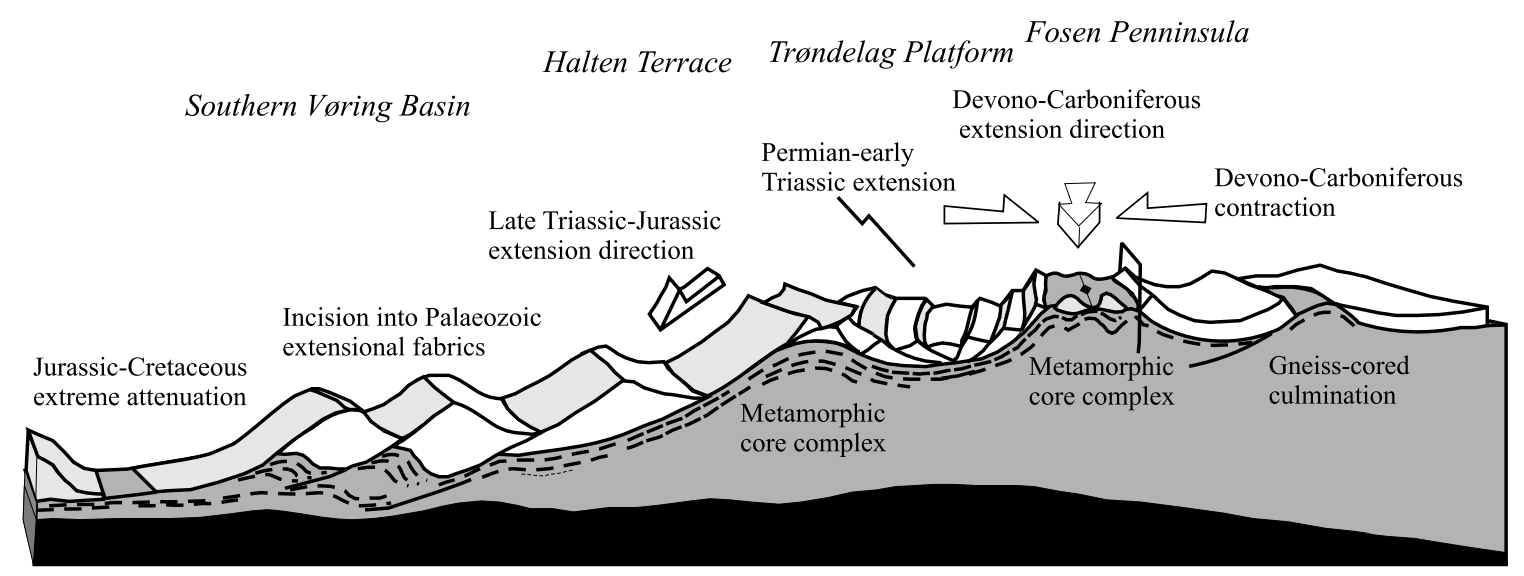

Fig. 7 Tentative model (not to scale) for the geometry of Palaeozoic and Mesozoic extensional detachments and the distribution of resultant core complexes and gneiss-cored culminations in a section that crosses the CNBW and passes offshore roughly along the trace of Fig. 5a.

(Osmundsen et al., 2002b). On the Halten Terrace, a pronounced unconformity on top of faulted Lower and ?lower Middle Jurassic strata indicates a main phase of faulting and rotation in Mid Jurassic time (Osmundsen et al., 2002b). The unconformity truncates a gentle syncline developed in the pre-Jurassic and Lower Jurassic strata, that may have developed during slip along the rampflat fault (op. cit.). To the south in the Slørebotn sub-basin, supradetachment half-graben basins experienced phases of rotation and syntectonic sedimentation in Bathonian to Volgian times (Jongepier et al., 1996). Thus, detachment faulting and associated late exhumation of metamorphic core complexes was probably important during Mid and Late Jurassic rifting, as well as during previous Devono-Carboniferous and PermoTriassic phases of extension. Late denudation of core complexes led to de-activation of detachment faults, such as the Palaeozoic-Early Mesozoic 
detachment beneath the Trøndelag Platform (Osmundsen et al., 2002b). In the Slørebotn Subbasin area (Fig. 5c), Bathonian-Volgian supradetachment rotation had apparently ceased, prior to the onset of Aptian sedimentation (Jongepier et al., 1996). In Bathonian to Volgian times, areas east of the Frøya High underwent fault-block rotation and sedimentation (Bøe and Skilbrei, 1998), resulting in an array of Mid to Late Jurassic basins along a NE-SW trend parallel to the MøreTrøndelag Fault Complex (Sommaruga and Bøe, in press). The Jurassic basins are unconformable upon Devonian sedimentary rocks and upon basement rocks that belong to the 'Upper Plate' configuration (following the generalised terminology of detachment faults, e.g. Wernicke, 1995; Lister et al., 1991) of the previous Devonian structural configuration.

\section{Discussion}

Detachment faulting and subsequent de-activation through core-complex denudation or low-angle incision appears to have taken place progressively and repeatedly in the Mid Norway area from the Devonian well into the Mesozoic times. Warping, incision and de-activation of Early Devonian extensional shear zones across type 3 culminations (Fig. 2) have been interpreted from onshore structural relationships (Braathen et al., 2002; Osmundsen et al., 2003); the offshore interpretations summarised above indicate that such modes of extensional deformation are applicable to important phases of Late Palaeozoic and Mesozoic structuring. We suggest that the Late DevonianEarly Carboniferous structural template involved the onshore gneiss-cored culminations observed onshore Mid Norway and their bounding structures in a sinistral, transtensional pull-apart that probably also included a number of NE-SW-trending faults now buried beneath Middle Triassic and younger strata on the Trøndelag Platform (see also Titus et al., 2002). The rift-style geometries displayed by the type 3 culminations (Fig. 2) and associated structures contrast with the low-angle ductile shear zones that characterised the earliest phase of extension. The structures associated with the type 3 culminations, thus appear to herald the structural styles associated with the later rift phases.

In the Mid Norway area, the maximum elongation trend changed by close to $90^{\circ}$, from ENEWSW in the Devonian to NW-SE in the Late Cretaceous and Early Tertiary (Gabrielsen et al.,
1999; Mosar et al., 2002). The exploitation of the Palaeozoic structural template in the Mesozoic was thus, probably preferential and dependent on the orientation and dip direction of inherited detachments and gneiss-cored culminations. The DevonoCarboniferous structural template included extension-parallel, NE-SW-trending, megascopic fold structures, as indicated by the Trøndelag synform and the Central Norway Basement Window (CNBW, Fig. 1), as well as a large number of kilometre-scale folds. The flanks of doubly plunging, antiformal culminations wrapped by detachment zones (type 2 culminations, Fig. 2) may thus have become the preferred loci for excision or incision in the Mesozoic, even if the extension direction had changed dramatically. The Hitra-Snåsa and Verran faults of the MTFC developed along the flanks of NE-SW-trending folds (Fig. 4; Séranne, 1992; Watts, 2001). Obliqueand dip-slip re-activation of segments of the MTFC took place in the Permian and the Mesozoic, respectively (Grønlie and Roberts, 1989; Bering, 1992; Watts, 2001). The Mesozoic phase of reactivation caused the formation of the inshore Jurassic Beitstadfjorden Basin as an extensional half-graben (Bøe and Bjerkli, 1989; Bering, 1992). The array of small Jurassic half-graben basins that straddle the Norwegian coast in the Trondheimsleia area, as well as parts of the SE Møre Basin margin, may have a similar explanation (Fig. 4; Bøe and Bjerkli, 1989; Bøe, 1991; Gabrielsen et al., 1999; Sommaruga and Bøe, in press).

Along the western margin of the (type 3) Børgefjell culmination, phases of re-activation with top-to-the-SSW and top-to-the-NW polarity were superposed on the main, Devono-Carboniferous, top-WSW ductile-to-brittle fault (Fig. 3). Thus, onshore, complex re-activation of the flanks of gneiss-cored culminations took place repeatedly during the formation of the passive margin. The possibility exists that individual faults in the offshore areas also experienced re-activation that involved transition from strike-slip to dip-slip or vice versa, depending on their orientations with respect to the changing stress field.

With the exception of the examples discussed above, the geographical extent of reactivation, deactivation and incision of core complexes and inherited detachments is unknown at present. We suspect, however, that variations on these themes were important during pre-Cretaceous structuring of the Mid-Norwegian margin.

Early to Mid Devonian, 40Ar/39Ar white mica cooling ages in the 395-385 Ma interval have been reported previously from gneiss-cored 
culminations, such as the CNBW and the Western Gneiss Region (WGR, Fig 1) (e.g. Dallmeyer et al., 1992; Berry et al., 1995; Eide et al., 2003). Thus, the Early to Middle Devonian time interval was an important one with respect to exhumation of highgrade metamorphic rocks through the $350-400^{\circ} \mathrm{C}$ temperature interval in the footwalls of largemagnitude extensional detachments (Chauvet et al., 1992; Andersen and Jamtveit, 1990; Eide et al., 2003; Kendrick et al., in press). The post-Mid Devonian exhumation history of the gneiss-cored culminations is less well-known. Whereas some onshore core complexes, such as the CNBW, were exhumed to the surface in ?Late Devonian-Early Carboniferous time, yielding material to 'Old Red' sedimentary basins (Eide et al., 2003), very little is known about the late stages of exhumation of a number of other gneiss-cored culminations. Carboniferous cooling ages of around 340 Ma have been obtained through 40Ar/39Ar geochronology performed on feldspars from the Sjona window of North-Central Norway (Eide et al., 2002), indicating cooling through temperatures of around $250^{\circ} \mathrm{C}$, at that time. A basement core sample from the well 6407/10-3 on the Frøya High yielded a biotite age of $395+4 \mathrm{Ma}$ and a K-feldspar age of $376+7 \mathrm{Ma}$ (Eide et al., 2003), indicating that in the Devonian, the rocks of the present-day Frøya High were being exhumed through the c. $350^{\circ} \mathrm{C}$ isotherm in the footwall of an extensional detachment, similar to those observed on the flanks of the type 2 culminations. Basement rocks that outcrop on the sea floor in the Griptarane area east of the Frøya High (Fig. 1), as well as on the islands in the Trondheimsleia area, belong to rock complexes that were in a high structural position in the Devonian configuration. This indicates truncation by faulting or erosion of the principal Devonian detachment between Griptarane and the Frøya High, prior to deposition of the Cretaceous strata that drape the high.

The Early to Late Devonian cooling history of the rocks positioned in the footwalls of the major, Mid Palaeozoic extensional structures provides a template for provenance studies on the MidNorwegian shelf. As the types 2 and 3 culminations became exposed at the surface, either through Mid Palaeozoic exhumation or by Late Palaeozoic and Mesozoic excision and incision, the culminations commenced their history as source areas for adjacent sedimentary basins. In the case of the CNBW, erosion at the surface started some time after the Mid/Late Devonian boundary, probably in the Late Devonian or Early Carboniferous, when material sourced from the CNBW was deposited in the Asenøy Basin (hangingwall of the Høybakken detachment, Fig. 1; Eide et al., 2003). Conversely, there is no evidence that coastal parts of the WGR were exhumed to the surface during deposition of the Middle Devonian basins of SW Norway (e.g. Cuthbert, 1991). Radiometric dating of mylonites related to sinistral strike-slip shear zones in the northern WGR indicate that these rocks were undergoing deformation under greenschist-facies conditions in the Mid/Late Devonian (Terry et al., 2000). Alluvial fan and fan-delta, gneiss-clast conglomerates banked against the SE margin of the Møre Basin indicate, however, that the northernmost WGR was yielding erosional products to the Slørebotn Sub-basin area in Triassic and Early Jurassic times (Smelror et al., 1994; Mørk and Stiberg, 2003).

The offshore core complexes are less well-known at present, due to their identification on a seismic grid are not dense enough for mapping. In the area close to well 6406/7-1 (Fig. 5a), it appears that the metamorphic core resided at depth during Jurassic faulting; in the area west of the Frøya High, however, an Upper Jurassic or earliest Cretaceous unit offlaps the main detachment and onlaps the most proximal tilted fault block in the hangingwall (Fig. 5b). This indicates that the abandoned detachment fault was exposed after the main incising event and that high-grade metamorphic rocks in the footwall, as well as the tilted halfgraben west of the Frøya High, may have yielded eroded debris to the adjacent Cretaceous Basin. $40 \mathrm{Ar} / 39 \mathrm{Ar}$ geochronology performed on white micas obtained from cores through parts of the offshore Mesozoic succession reveal a spectrum of Early to Late Devonian, white mica cooling ages (Sherlock, 2001). These record Mesozoic erosion of rocks exhumed in the type 2 (and 3?) culminations. Sherlock (2001) did, however, conclude that the dated micas had experienced at least one phase of recycling since their erosion off the onshore tectonothermal template. The abandonment, partially or completely, of parts of an extensional system and its role in cannibalisation and recycling of basins is only partly understood for the Mid-Norwegian margin. An excision scenario would, however, provide an explanation for deactivation and for the commonly cited (e.g. Blystad et al., 1995) westward younging of fault activity. Both the excision and the incision models would lead to deactivation of more proximal parts of the extensional system, leaving older arrays of faults and half-grabens in a structurally high position where they could be eroded and recycled into the younger parts of the rift basin. 


\section{Conclusions}

In the Mid Norway area, onshore core complexes and gneiss-cored culminations were exhumed to the surface in the footwalls of extensional shear zones and low-angle normal faults from the Late Devonian-Early Carboniferous. Since then, the culminations started to supply adjacent basins with debris that preserves the 40Ar/39Ar signature and, thus, the cooling history of the source rocks from which it was eroded. The recent AFT data show that faulting along the Møre-Trøndelag trend continued at least into the Late Mesozoic. Late Palaeozoic and Mesozoic stages of exhumation were strongly dependent on the location and geometry of new faults that formed by excisement, incisement or re-activation of the previous structures. Interpretation of longoffset seismic reflection data strongly indicates that low-angle normal-faulting and core-complex denudation continued into the Mesozoic; however, the lateral extent of the core complexes and the detachment faults interpreted in the offshore areas (Osmundsen et al., 2002b) and their influence on shallower-level extensional faulting is not known in detail. There is a considerable potential, in our view, residing in the links between deep and shallow structure and, in turn, in their influence on synand post-rift stratigraphic architecture. A better coverage of low-temperature thermochronological data (AFT, U-Th-He) is essential to improve our understanding of the relationship between the source area uplift and the offshore basin formation in Late Palaeozoic and Mesozoic times.

\section{Acknowledgements}

The studies summarised in this paper were conducted under the umbrella of the BAT project, hosted by the Norwegian Geological Survey (NGU). We thank the sponsors to the BAT project, including Eni Norge, BP, ChevronTexaco, ConocoPhillips, ExxonMobil, Norsk Hydro, A/S Norske Shell and Statoil. We thank Geco-Prakla for permitting an interpretation on the proprietary long-offset seismic data.

\section{References}

Allen, K.C., 1976. Devonian spores from outer Trøndelag. Norsk Geol. Tidsskr., 56, 437-448.

Andersen, T.B. and Jamtveit, B., 1990. Uplift of deep crust during orogenic extensional collapse: a model based on field studies in the Sogn-Sunnfjord area of Western Norway. Tectonics, 9: 1097-1111.

Bering, D., 1992. The orientation of minor fault plane striae and the associated deviatoric stress tensor as a key to the fault geometry in part of the Møre-Trøndelag fault zone, on-shore central Norway. In: R.M. Larsen, H. Brekke, B.T. Larsen and E. Talleraas (Editors), Structural and Tectonic Modelling and its Application to Petroleum Geology. Norwegian Petroleum Society (NPF), Special Publication 1, Elsevier, Amsterdam, pp. 83-90.

Berry, H.N., Lux, D.R., Andresen, A. and Andersen, T.B., 1995. Progressive exhumation during orogenic collapse as indicated by 40Ar/39Ar ages from different structural levels, southwest Norway. Geonytt 22 (1): 20-21.

Blystad, P., Brekke, H., Færseth, R.B., Larsen, B.T., Skogseid, J. and Tørudbakken, B., 1995. Structural elements of the Norwegian Continental Shelf. Part II: The Norwegian Sea Region. NPD, Bull., 8.

Braathen, A., Nordgulen, Ø., Osmundsen, P.T., Andersen, T.B., Solli, A. and Roberts, D., 2000. Devonian, orogen-parallel, opposed extension in the Central Norwegian Caledonides. Geology, 28: 615-618.

Braathen, A., Osmundsen, P.T., Nordgulen, Ø., Roberts, D. and Meyer, G., 2002. Orogen-parallel extension of the Caledonides in northern Central Norway: an overview. Nor. J. Geol. (NGT), 82: 225-242.

Bøe, R., 1991. Structure and seismic stratigraphy of the innermost mid-Norwegian continental shelf: an example from the Frohavet area. Mar. Petrol. Geol., 8: 140-151.

Bøe, R. and Bjerkli, K., 1989. Mesozoic sedimentary rocks in Edøyfjorden and Beitstadfjorden, Central Norway: Implications for the structural history of the Møre-Trøndelag fault zone. Mar. Geol., 87: 287-299.

Bøe, R. and Skilbrei, J.R., 1998. Structure and seismic stratigraphy of the Griptarane area, Møre Basin margin, mid-Norway continental shelf. Mar. Geol., 147: 85-107.

Chauvet, A., Kienast, J.R., Pinarden, J.L. and Brunel, M., 1992. Petrological constraints and PT path of Devonian collapse tectonics within the Scandinavian mountain belt (Western Gneiss Region, Norway). J. Geol. Soc., London, 149: 383-400.

Chauvet, A. and Séranne, M., 1994. Extension-parallel folding in the Scandinavian Caledonides: implications for late-orogenic processes. Tectonophysics, 238: 31-54.

Coates, B.H., Zeltner, D.L., Carter, B.T., Steltenpohl, M.G., Andresen, A. and Kunk, M.J., 1999. 40Ar/39Ar and structural investigations of extensional development of the North-Central Norwegian margin. Abstracts with programs, Geological Society of America, 31 (7): 118.

Cuthbert, S.J., 1991. Evolution of the Devonian Hornelen Basin, Western Norway: new constraints from petrological studies of metamorphic clasts. In: Morton, A.C., Todd, S.P. and Haughton, P.D.W. (Editors), Developments in sedimentary provenance studies. Geol. Soc., London, Spec. Publ., 57: 343-360.

Dallmeyer, R.D., Johansson, L. and Möller, C., 1992. Chronology of Caledonian high-pressure granulite-facies metamorphism, uplift and deformation within northern parts of the Western Gneiss Region. Geol. Soc. Am. Bull., 104: 444-455.

Eide, E.A., Haabesland, N.E., Osmundsen, P.T., Kendrick, M.A., Andersen, T.B. and Roberts, D., 2003. 40Ar/39Ar geochronology and indirect dating of continental sedimentary rocks: Late Devonian-Early Carboniferous 'Old Red Sandstone' discovered in outer Trøndelag. In: H.A. Nakrem (Editor), Abstracts and Proceedings of Geological Society of Norway (NGF) 1, Vinterkonferansen 2003.

Eide, E.A., Osmundsen, P.T., Meyer, G.B. and Kendrick, M.A., 2002. An 40Ar/39Ar geochronology profile through the Nesna Shear Zone, North-Central Norway: a Middle Devonian — Early 
Carboniferous ductile extension and unroofing record. Nor. J. Geol. (NGT), 82: 317-339.

Fossen, H., 1992. The role of extensional tectonics in the Caledonides of southern Norway. J. Struct. Geol., 14: 1033-1046.

Fossen, H., Odinsen, T., Færseth, R.B. and Gabrielsen, R.H., 2000. Detachments and low-angle faults in the northern North Sea rift system. In: Nøttvedt et al. (Editors), Dynamics of the Norwegian margin. Geological Society, London, Special Publications, 167: 105-131.

Gabrielsen, R.H., Odinsen, T. and Grunnaleite, I., 1999. Structuring of the Northern Viking Graben and the Møre Basin; the influence of basement structural grain and the particular role of the MøreTrøndelag Fault Complex. Mar. Petrol. Geol., 16: 443-465.

Gawthorpe, R.L., Sharp, I., Underhill, J.R. and Gupta, S., 1997. Linked sequence stratigraphic and structural evolution of propagating normal faults. Geology, 25: 795-798.

Grunnaleite, I. and Gabrielsen, R.H., 1995. The structure of the Møre Basin. Tectonophysics, 252: 221-251.

Grønlie, A. and Roberts, D., 1989. Resurgent strike-slip duplex development along the Hitra-Snåsa and Verran Faults, Møre-Trøndelag Fault Zone, Central Norway. J. Struct. Geol., 11: 295-305.

Grønlie, A., Nilsen, B. and Roberts, D., 1991. Brittle deformation history of fault rocks on the Fosen Peninsula, Trøndelag, Central Norway. Norg. Geol. Unders. Bull., 421: 39-57.

Haller, J., 1971. Geology of the East Greenland Caledonides. John Wiley and Sons. 381 pp.

Hovius, N. and Leeder, M.R., 1998. Clastic sediment supply to basins. Basin Res., 10: 1-5.

Jarvik, E., 1949. On the Middle Devonian Crossopterygians from the Hornelen field in western Norway. Universitetet i Bergen Aarbok, Naturvidenskapelig rekke, 8.

Jongepier, K., Rui, J.C. and Grue, K., 1996. Triassic to Early Cretaceous stratigraphic and structural development of the northeastern Møre Basin margin, off Mid-Norway. Norsk Geol. Tidsskr., 76: 199-214.

Kendrick, M., Eide, E.A., Roberts, D. and Osmundsen, P.T., 2004. The Mid-Late Devonian Høybakken Detachment, Central Norway: 40Ar-39Ar evidence for prolonged late/post-Scandian extension and uplift. Geol. Mag., 141 (3): 329-344.

Kolderup, C.F., 1921. Kvamshestens Devonfelt. Bergens Museum Aarbok 1920-21, Naturvidenskabelig Række, 4

Krabbendam, M. and Dewey, J.F., 1998. Exhumation of UHP rocks by transtension in the Western Gneiss region, Scandinavian Caledonides. In: R.E. Holdsworth, R.A. Strachan and J.F. Dewey (Editors), Continental transpressional and transtensional tectonics. Geol. Soc., London, Spec. Publ., 135: 159-181.

Leeder, M.R., Harris, T. and Kirby, M.J., 1998. Sediment supply and climate change: implications for basin stratigraphy. Basin Res., 10: 7-18.

Lister, G.S. and Davis, G.A., 1989. The origin of metamorphic core complexes and detachment faults formed during Tertiary continental extension in the northern Colorado River region, U.S.A. J. Struct. Geol., 11: 65-94.

Lister, G.S., Etheridge, M.A. and Symonds, P.A., 1991. Detachment models for the formation of passive continental margins. Tectonics, 10: 1038-1064.

Manatschal, G., Froitzheim, N., Rubenach, M.J. and Turrin, B.D., 2001. The role of detachment faulting in the formation of an ocean-continent transition: insights from the Iberia abyssal plain. In: Wilson, R.C.L., Whitmarsh, R.B., Taylor, B. and Froitzheim, N. (Editors), Non-Volcanic Rifting of Continental Margins: A Comparison of Evidence from Land and Sea. Geological Society, London, Special Publications, 187: 161-189.

Mosar, J., Osmundsen, P.T., Sommaruga, A., Torsvik, T.H. and Eide, E.A., 2002. Greenland-Norway separation: a geodynamic model for the North Atlantic. Nor. J. Geol. (NGT), 82: 281-298.
Mørk, M.B.E. and Stiberg, J.P., 2003. Basement erosion and Mesozoic sandstone provenance in the Møre margin area. In: Norsk Petroleumsforening, extended abstracts: Petroleum Exploration and Production in Environmentally Sensitive Areas, Ålesund Norway, 5-7th May 2003, pp. 41-44.

Norton, M.G., 1986. Late Caledonian extension in western Norway: a response to extreme crustal thickening. Tectonics, 5: 195-204.

Olesen, O., Lundin, E., Nordgulen, Ø., Osmundsen, P.T., Skilbrei, J.R., Smethurst, M.A., Solli, A., Bugge, T. and Fichler, C., 2002. Bridging the gap between the onshore and offshore geology in Nordland, northern Norway. Nor. J. Geol. (NGT), 82: 243-262.

Osmundsen, P.T. and The BAT team, 2002a. Core complexes, gneiss-cored culminations and detachments, Mid Norway. In: Eide (Editor), BATLAS - Mid Norway plate reconstruction atlas with global and Atlantic perspectives. A product of the Basin Analysis and applied thermochronology on the Mid Norwegian shelf (BAT) project, 1998-2002. ISBN: 82-7385-106-0. pp. 64-65.

Osmundsen, P.T., Braathen, A., Nordgulen, Ø., Roberts, D., Meyer, G.B. and Eide, E., 2003. The Devonian Nesna shear zone and adjacent gneiss-cored culminations, North-Central Norwegian Caledonides. J. Geol. Soc., London, 160: 137-150.

Osmundsen, P.T., Sommaruga, A., Skilbrei, J.R. and Olesen, O., 2002b. Deep structure of the Mid Norway rifted margin. Nor. J. Geol. (NGT), 82: 205-224.

Ramberg, H., 1980. Diapirism and gravity collapse in the Scandinavian Caledonides. In: Phillips, W.E.A. and Johnson, M.R.W. (Editors) Deformation and metamorphism in the Caledonian Orogen. J. Geol. Soc., London, 137: 261-270.

Redfield, T.F., 2002. Apatite fission track data from the Møre Trøndelag fault complex and the Fosen Peninsula, central Norway. In: A. Hurst (Editor), Onshore-Offshore Relationships on the Nordic Atlantic Margin. NGF Abstracts and proceedings 2, 2002 of the Norwegian Petroleum Society (NPF) and Norwegian Geological Society (NGF) Conference, 7-9th Oct. Trondheim, pp. 166-168.

Redfield, T.F., Torsvik, T.H., Andriessen, P.A.M. and Gabrielsen, R.H., in press. Mesozoic and Cenozoic tectonics of the Møre Trøndelag Fault Complex, central Norway: constraints from new apatite fission track data. Physics and Chemistry of the Earth.

Roberts, D., 1998. High-strain zones from meso- to macro-scale at different structural levels, Central Norwegian Caledonides. J. Struct. Geol., 20: 111-119.

Rykkelid, E. and Andresen, A., 1994. Late Caledonian extension in the Ofoten area, northern Norway. Tectonophysics, 231: 157-169.

Séranne, M., 1992. Late Palaeozoic kinematics of the MøreTrøndelag Fault Zone and adjacent areas, central Norway. Norsk Geol. Tidsskr., 72: 141-158.

Sherlock, S., 2001. Two-stage erosion and deposition in a continental margin setting; an 40Ar/39Ar laserprobe study of offshore detrital white micas in the Norwegian Sea. J. Geol. Soc., London, 158: 793-799.

Sindre, A., 1998. Tolkning av dyp til basement under de kaledonske dekkebergartene i Nordland fra gravimetriske data. Norg. Geol. Unders. Rep. 97.179, 24 pp.

Skilbrei, J.R., Olesen, O., Osmundsen, P.T., Kihle, O., Aaro, S. and Fjellanger, E., 2002. A study of basement structures and onshoreoffshore correlations in Central Norway. Nor. J. Geol. (NGT), 82: $263-280$.

Skilbrei, J.R., Skyseth, T. and Olesen, O., 1991. Petrophysical data and opaque mineralogy of high-grade and retrogressed lithologies: implications for the interpretation of aeromagnetic anomalies in northern Vestranden, Central Norway. Tectonophysics, 192: 21-31.

Skogseid, J., Pedersen, T. and Larsen, V.B., 1992. Vøring Basin: subsidence and tectonic evolution. In: Larsen, R.M., Brekke, H., Larsen, B.T. and Talleraas (Editors), Structural and Tectonic Modelling and its Application to Petroleum Geology. Norwegian 
Petroleum Society (NPF) Special Publication 1, Elsevier, Amsterdam, pp. 55-82.

Sommaruga, A. and Bøe, R., 2002. Geometry and subcrop maps of shallow Jurassic basins along the Mid-Norway coast. Mar. Petrol. Geol., 19: 1029-1042.

Talbot, C.J. and Ghebreab, W., 1997. Red Sea detachment and basement core complexes in Eritrea. Geology, 25: 655-658.

Terry, M.P., Robinson, P., Hamilton, M.A. and Jercinovic, M.J., 2000. Monazite geochronology of UHP and HP metamorphism, deformation and exhumation, Nordøyane, Western Gneiss Region, Norway. AAPG Mineral., 85: 1651-1664.

Titus, S.J, Fossen, H., Pedersen, R.B., Vigneresse, J.L. and Tikoff, B., 2002. Pull-apart formation and strike-slip partitioning in an obliquely divergent setting, Leka Ophiolite, Norway. Tectonophysics, 354: 101-1019.

Watts, L.M., 2001. The Walls Boundary Fault Zone and the MøreTrøndelag Fault Complex: a case study of two reactivated fault zones. Unpublished Ph.D. thesis, University of Durham, 550 pp.

Wernicke, B., 1985. Uniform-sense normal simple shear of the continental lithosphere. Can. J. Earth Sci., 22: 108-125.

Whitmarsh, R.B., Dean, S.M., Minshull, T.A. and Tompkins, M., 2000. Tectonic implicationsof exposure of lower continental crust beneath the Iberia Abyssal Plain, Northeast Atlantic Ocean: Geophysical evidence. Tectonics, 19: 919-942. 